\title{
Environmental management and proposals to improve the wage system
}

\author{
Alexander Rodionov ${ }^{1}$, Marina Danilina ${ }^{1,2,3,4^{*}}$, Galina Dmitrieva ${ }^{5}$, Nikolai Pimenov ${ }^{1}$, \\ Evgeniy Burikin ${ }^{4}$, and Fedor Buraev ${ }^{4}$ \\ ${ }^{1}$ Research Institute VNII of Labor, Ministry of Labour of Russia, Zemlyanoy Val, 34, 105064 \\ Moscow, Russia \\ ${ }^{2}$ Finance University under the Government of the Russian Federation, Leningradsky prosp., 49, \\ 125993 Moscow, Russia \\ ${ }^{3}$ Russian Economic University, Stremyanny per., 36, 117997 Moscow, Russia \\ ${ }^{4}$ Moscow University imeni S.Yu. Vitte (MUIV), $2^{\text {nd }}$ Kozhukhovsky proezd, 12, stroyeniye 1, 115432, \\ Moscow, Russia \\ ${ }^{5}$ Saint-Petersburg State University of Aerospace Instrumentation, Bolshaya Morskaia str. 67, 190000, \\ Saint-Petersburg, Russia
}

\begin{abstract}
In today's global economy, the importance of environmental and social responsibility is constantly growing. There are thousands of environmental and social standards and guidelines around the world today. These guidelines and standards define requirements and objectives. However, the main problem is their practical implementation and implementation. The Environmental and Social Management System (ESMS) enables companies to integrate the requirements of these guidelines and standards into their operations by organizing a set of welldefined, iterative processes. One aspect of this system is the remuneration system. On the basis of content analysis and analysis of statistical data, the authors develop proposals for improving this system.
\end{abstract}

\section{Introduction}

For many years, humankind has had a limited understanding of its impact on the environment. However, at present, the awareness that natural resources are limited and human activities have both short-term and long-term impact on the environment is deep enough. Many people understand that the production of goods and the provision of services leads not only to the depletion of natural resources, but also entails the emergence of various environmental problems. Considerable efforts are devoted to solving old and preventing new environmental problems.

In recent years, many European countries have achieved significant improvements thanks to stricter environmental legislation and active implementation of preventive measures. Society and product manufacturers changed their attitude towards the

\footnotetext{
${ }^{*}$ Corresponding author: marinadanilina@yandex.ru
} 
environment and environmental issues began to play a significant role in the decisionmaking process.

Environmental management is a set of measures, including the management of resources, production processes and products, aimed at reducing the environmental impact of production activities and increasing the efficiency of the enterprise.

Environmental management can be used in any industrial or service organization. It is used by both large and small businesses. For example, environmental management systems operate in various industries, in retail outlets, in travel agencies, educational institutions, etc.

Companies today face a number of serious environmental and social challenges. All of these problems are surmountable, however, if they are not identified and solutions are not found on time, it will negatively affect your profitability, reputation and business, prospects.

These challenges include rising costs of energy and raw materials, increased authority and influence of government agencies in environmental management and health and safety, and rapid growth in consumer awareness and concern about environmental and social issues. These risks are in addition to the main business risks that threaten the achievement of targets, strengthen the brand reputation and increase consumer confidence. All of these risks ultimately have financial implications.

Going internationally is vital to the success of many businesses, but it also means that the exported goods and services are subject to heightened demands from international law, national industry standards and consumer requirements. Many of these requirements increasingly relate to environmental and social business practices. The above risks, requirements and external pressures on your business are the main drivers for implementing a management system.

The management system will allow you to consistently identify and timely resolve the problems facing your business, and thus prevent potential risks from turning into real problems. The implementation of an Environmental and Social Management System (ESMS) can provide direct commercial benefits. Resource saving and more rational consumption of energy and raw materials can reduce production costs. Reducing the volume of waste generation and emissions, organizing their processing are able to minimize the constantly growing costs of waste disposal. Indeed, it is possible to organize the processing of organic waste, turning them into fuel or energy resources, and thereby increase the sustainability of your business and reduce costs. A management system can help to effectively organize processes, and thus align costs with industry standards and identify possible ways to reduce production and operating costs.

Social benefits are equally tangible. Clear and transparent personnel policies and procedures in this area improve communication between employees and management, which helps to prevent problems in the field of labor relations. Effective health and safety management procedures can identify and eliminate risk factors in workplaces and processes, or mitigate their potential negative impacts. This will not only reduce the number of injuries and fatalities, but also provide direct business benefits by reducing absenteeism, employee turnover rates, and insurance payments to workers' compensation funds. Many companies are already using management systems for quality control. The Environmental and Social Management System (ESMS) simply extends this approach to managing the impacts of your business on the environment, workers and other external stakeholders. The ultimate goal is to create a single integrated management system, instead of separate quality management systems, health and safety, and environmental protection. One aspect of this system is wages. 


\section{Materials and methods}

The Environmental and Social Management System (ESMS) enables companies to integrate the requirements of these guidelines and standards into their operations by organizing a set of well-defined, iterative processes. One aspect of this system is the remuneration system. On the basis of content analysis and analysis of statistical data, the authors develop proposals for improving this system.

\subsection{Socio-economic content of the category "wages"}

The most important categories that characterize the remuneration of employees for work are: "wages" and "wages". Their substantive characteristics are recorded in the Labor Code of the Russian Federation, definitions of the Constitutional Court of the Russian Federation, Conventions and Recommendations of the ILO, etc. Note that the ambiguity of their interpretation in different countries is explained by the complexity of their nature, reflection of the specifics of the social structure and a wide range of views on the nature of the distribution of the results of labor activity. Remuneration for labor in its semantic space includes the category of "wages".

The study of the conceptual apparatus of these categories is not so much a theoretical as a practical issue, because their substantive characteristics and the legal field that they form serve as an instrument of legislative, contractual regulation of population incomes and social protection of the population of almost any country.

The category "wages" is one of the most frequently used definitions used to describe social and labor relations, social and budgetary policies of economically developed countries. Its interpretation has changed significantly over the past two centuries. The vector of development of theory and practice was directed from exceptional economic to socio-economic content.

This was due to the formation of a market economy and the reflection of the role of wages of employees in the system of commodity-money relations. Thus, in prerevolutionary Russia, the category of "wages" was interpreted as: "a certain historical form of income closely related to the entire modern economic system and representing one of the three main distribution categories that characterize this system (land rent, entrepreneurial income and wages) ... Wages are where employees are personally free and enjoy civil legal capacity. "

The above definition of "wages" reflects the most typical property of social relations associated with their commodity-money, that is, economic nature. It reflects the method of receiving wages, the most important prerequisites of which are:

a) wages are one of the three forms of distribution of material wealth, it is the main source of income for employees;

b) the subject of labor is an employee who is free from a legal point of view and has no obstacles to offer his work to the employer;

c) wages are paid in cases where the employee and the employer, through a personal employment contract, reach an agreement on the ratio of labor and the amount of remuneration.

According to Art. 129 of the Labor Code of the Russian Federation "Wages (employee remuneration) are the remuneration for labor depending on the qualifications of the employee, the complexity, quantity, quality and conditions of the work performed. It is as well the compensation payments (additional payments and allowances of a compensatory nature, including for work in conditions deviating from normal, work in special climatic conditions and in areas exposed to radioactive contamination, and other payments of a 
qualification nature) and incentive payments (additional payments and incentive payments, bonuses and other incentive payments)".

This interpretation of the essence of wages corresponds to the norms of Art. 1 of the ILO Convention No. 95 "On the Protection of Wages". In which it discloses this concept as follows: "wages are, regardless of the name and method of calculation, any remuneration or any earnings calculated in money and established by an agreement or national legislation. And which is the case, by virtue of written or an oral contract of employment, when the employer pays the worker for work that is either performed or must be performed, or for services that are either rendered or must be rendered. "

According to the position of the ILO, OECD, UN and World Bank, when using the System of National Accounts, the category of "remuneration" of employees includes two main elements:

- salary is a material remuneration that is paid by the employer to an employee for the work he has done properly, and its size is stipulated in advance by the labor contract and is designed to provide the employee with material resources sufficient for his normal life and his family members;

- remuneration of labor includes wages plus payments of benefits and pensions at the expense of insurance contributions of employers (employees) to social insurance funds (pension, health insurance, insurance against industrial accidents and occupational diseases, in connection with unemployment and temporary disability) for reservation in case of social risks of disability or employment.

The measures we propose to improve the remuneration system can be divided into two areas:

1 Proposals to improve the tariff part of wages

2. Proposals for improving the above-tariff part of wages

\subsection{Proposals to improve the tariff part of wages}

The following recommendations can be distinguished for improving the systems of remuneration for employees of state and municipal institutions.

At present, in most state and municipal institutions, official salaries are established in accordance with the qualification levels approved in the PCG.

In order to ensure the share of salaries in the structure of wages at a level of at least $50 \%$, according to the Unified Recommendations, it is advisable to maintain the use of the PQG (with further clarification and specification), but with the use of the basic minimum salaries, the establishment of which is enshrined in Article 144 of the Labor Code of the Russian Federation, with This is to tie the size of the minimum salary of a worker of the 1st category to the size of the cost of the actual concept of "minimum consumer budget" proposed in this work.

To date, there are no guidelines for setting salaries in budgetary institutions, with the exception of the minimum wage, which is equal to the subsistence minimum, but is not mandatory in terms of setting minimum salaries. In turn, the PM is formed on the basis of the consumer basket and reflects the value of the minimum set of food products, non-food products and services, as well as mandatory payments and fees, necessary to preserve human health and ensure his life.

At the same time, the minimum permissible level of satisfaction of the material and spiritual needs of a person engaged in labor, as well as the basic value and structure of consumption of goods and services necessary for a person for normal life, are more accurately and reasonably characterized by the concept of "minimum consumer budget". 
The consumer budget is an economic category that characterizes the structure and balance of income and expenses of people (families and single people, employed and unemployed, etc.), as well as the structure of needs, which determines the directions of using income for the purchase of various goods and services, for investments, savings and other purposes. Consumer budgets differ in the degree to which basic physiological, social and spiritual needs are met. The expenditure side of the consumer budget is determined by the following factors:

1. Physiological human needs (biological factor).

2. Type and nature of work (professional factor).

3. The level of cultural development of a person (general cultural factor).

4. Working conditions: the level of mechanization, automation, hygienic conditions, working hours and rest (production factor).

5. Habitual lifestyle and standard of living (socio-historical factor).

6. Age and sex composition of the family (demographic factor).

7. Natural and climatic conditions (geographic factor).

8. National customs (ethnic factor).

9. Intentions and moods of people (psychological factor).

There are many combinations of the above factors that determine needs and form consumer budgets for various categories of people.

At the same time, the minimum consumer budget is one of the main system-forming basic budgets (along with the subsistence minimum), which is proposed to be consolidated in the regulatory framework by federal law. The minimum consumer budget is a criterion for a socially acceptable level of reproductive consumption (calculated at the lowest level of welfare).

1. The Decree of the President of the USSR No. UP-1995 of May 21, 1991 "On the minimum consumer budget" provides for the development and introduction into practice of the minimum consumer budget, calculated according to a unified methodology for the whole country, republics and regions.

At the same time, it is assumed that minimum consumer budgets will be used as social standards when predicting changes in the standard of living of the population, determining the minimum wages, pensions, allowances, scholarships and other social payments, as well as government spending on food in hospitals, boarding schools, schools, preschool and others. institutions of the social sphere.

This decree has not been canceled, but due to the absence of the concept of "minimum wage" in the current legislation, it is not applied. According to this Decree, the minimum consumer budget determines the costs of purchasing a set of consumer goods and services to meet the basic physiological and socio-cultural needs of a person.

2. In the Decree of the President of the Russian Federation No. 210 of March 2, 1992 "On the system of minimum consumer budgets of the Russian Federation", which is currently in force, it is determined to develop a republican minimum consumer budget based on a set of consumer goods and services that satisfy basic material and spiritual needs. , as well as to carry out a gradual increase in the minimum wage, pensions, benefits, scholarships and other social payments, taking into account consumer budgets and real economic opportunities.

As an anti-crisis measure to overcome the current socio-economic situation, the Decree decided to determine the level (budget) of the subsistence (physiological) minimum, differentiated by the main social groups.

This budget characterizes the minimum permissible limits of consumption of the most important material goods and services (food, sanitation and hygiene items, medicines, housing and communal services). The decree is valid, but it is applied only in terms of calculating the levels of the subsistence (physiological) minimum (PM), despite the fact 
that this measure was introduced only to get out of the crisis state and is not relevant at the current time.

In addition to the above normative legal acts, the category "minimum consumer budget" is found in regional laws. For example, the Law of the Republic of Tatarstan No. 31-ZRT dated July 23, 2008 "On the minimum consumer budget in the Republic of Tatarstan" provides for the use of the minimum consumer budget, in particular, to justify the minimum wage established in the Republic of Tatarstan, which cannot be lower than the minimum wage.

According to this document, the minimum consumer budget is the value of a balanced set of food products, non-food products and services, as well as mandatory payments and fees necessary to maintain an active physical condition of a person and the reproduction of the labor force.

Thus, the "minimum consumer budget" is applied in the current legislation at the regional level, but not at the federal one.

Taking into account the fact that the level of wages should contribute to the reproduction of the labor force and correspond to the cost estimate of the restoration of the ability to work, taking into account the socio-cultural needs of a person, it is advisable, in our opinion, to use the "minimum consumer budget" as the base salary (official salary), and not anti-crisis living wage.

In 2018, Deputy Prime Minister of the Russian Federation Tatyana Alekseevna Golikova, who at that time was the Chairman of the Accounts Chamber of the Russian Federation, spoke at the board of the Ministry of Finance with a statement on the need to move to a minimum consumer budget as the basis of a targeted social protection system.

To justify the recruitment and calculation of the cost size of the minimum consumer budget, the following should be used: the subsistence minimum budget, approved by the RF Government decree of February 17, 1999, No. 192 with subsequent amendments and additions; Resolution of the Government of the Russian Federation of January 28, 2013 No. 54; a set of the minimum (restorative) budget of a worker engaged in light work, prepared by the All-Union Center for the Study of Labor and Social Affairs and the Research Institute of Labor.

The food sets included in the minimum consumer budget are calculated on the basis of a set of food items for a man of working age engaged in light labor in the constituent entities of the Russian Federation with favorable natural and climatic conditions.

The cost of the minimum consumer budget for a beginner worker engaged in light work in normal working conditions (with a minimum level of labor complexity) will amount to 13,432.51 rubles. per month in March 2019 prices. The share of food in the cost of the budget is $43.1 \%$, which roughly corresponds to its share in the normative-statistical method for determining the subsistence minimum of the working-age population.

Taking into account that inflation for the period March-September 2019 amounted to $1.1 \%$, as of September 2019, the cost of the minimum consumer budget is 13,579.82 rubles. Detailed examples of calculating the cost of the minimum consumer budget are presented in Appendix D. The above calculation of the cost of the minimum consumer budget was made on the basis of data on the minimum cost of the specified sets of goods and services and should subsequently be revised taking into account the inflation rate and the consumption basket.

\subsection{Proposals for improving the above-tariff part of wages}

When analyzing the provisions on remuneration of employees of state and municipal institutions, as well as sectoral (intersectoral) agreements, it was revealed that in most cases 
the procedure for establishing compensation payments corresponds to the current labor legislation or even exceeds. In this connection, in terms of compensation payments, we propose to keep the procedure established by the current labor legislation.

Currently, by Order of the Ministry of Labor of Russia dated April 26, 2013 No. 167n (as amended and supplemented from February 20, 2014), it is recommended to use the following in wage systems, labor contracts and supplementary agreements to labor contracts with employees of state and municipal institutions incentive payments:

1) payments for intensity and high performance,

2) payments for the quality of work performed,

3) payments for the length of service, length of service,

4) bonus payments based on performance.

At the same time, Section IV of the Program for the gradual improvement of the remuneration system in state (municipal) institutions for 2012-2018, approved by the order of the Government of the Russian Federation of November 26, 2012 No. 2190-r (as amended and supplemented from September 14, 2015 No. ) it is envisaged to improve the system of incentive payments based on "the need to link the increase in wages with the achievement of specific indicators of the quality and quantity of state (municipal) services (work performance) provided on the basis of: ... abolishing ineffective incentive payments; ...".

In order to optimize the remuneration system for employees of state and municipal institutions, it is recommended to exclude from the list such incentive payments as payments for the intensity and high results of work, payments for the quality of work performed, since they do not have a transparent and understandable application procedure.

In addition, these payments duplicate the concept of performance indicators for employees, which were introduced together with the "effective contract".

Incentive payments for intensity and high performance; employees are paid for the quality of work performed, taking into account the criteria for assessing the effectiveness and quality of employees' work, but the established criteria do not correspond to the nature of these incentive payments and include indicators reflecting the results of work, some of which cannot be evaluated.

Therefore, it is proposed to establish one incentive payment, for example, a bonus based on performance for a specific period (month, quarter, half year, year), taking into account performance indicators, including indicators such as intensity, performance assessment and quality of work. Next, let's take a closer look at this approach.

The most important stimulating factor is the establishment of a direct link between wages and the final results of work.

The analysis of the relationship between incentive payments and the performance indicators of the institution and employees, carried out in state and municipal institutions of the constituent entities of the Russian Federation, showed that the most important incentive factor is the establishment of a direct connection between wages and the final results of work.

This leads to an increase in the interest of employees in the results of their work, an increase in the level and quality of services provided, etc. Practice has shown that when indicators of employee performance are applied, the implementation of the plan increases, the number of complaints decreases, and the quality of services is increased. At the same time, with the deprivation of incentive payments for objective reasons, the quality of work improves in the future, and a decrease in the amount of payments contributes to an improvement in the performance of other employees.

Thus, we can conclude that the use of incentive payments, depending on the results of a specialist's work and charged according to understandable and objective indicators, has a positive effect on the work of staff and the institution as a whole. The use of such a system 
affects the reduction of costs, the reduction of industrial conflicts, incentives for workers to improve their qualifications. When establishing performance indicators in an institution, the following principles should be followed:

- performance indicators must be established by categories of workers / positions;

- performance indicators should be objective and reflect the effectiveness and quality of work;

- performance indicators should take into account individual achievements and personal contribution to work results;

- performance indicators should contribute to the "transparency" of incentive payments.

Also, institutions should analyze the impact of the developed indicators and criteria, and, if necessary, refine them and update them.

For the convenience of calculating the final assessment of the implementation of performance indicators, it is recommended to automate the incentive system. A good example is the Volgograd region, where the automated system "Evaluation of performance indicators of medical organizations" is used, on the basis of which an end-to-end rating of medical organizations is formed and, based on the results of the assessment, proposals are made for bonuses to the heads of medical organizations.

\section{Results and discussions}

In the second half of the XIX - early XX centuries. the majority of people, thanks to the successes of science and technology, have developed an idea of the absolute superiority of man over nature. And the subsequent successes in the exploration of outer space, in the field of microelectronics and computer technology, the chemical industry only strengthened anthropocentrism - the concept of man as the center of the Universe, which has developed since the Renaissance.

People began to forget that they are also a part of nature, a biological species, that in their life it is impossible to circumvent the laws of nature, they can only be used. In June 1972, the first UN international conference on the environment was held in Stockholm, followed by numerous meetings at the level of governments and scientific organizations.

There was claimed a warning about the threat of existence, which our planet faced for the first time in its history. According to a resolution adopted in 1972, the holiday was established. The UN Conference on Environment and Development, which was held in 1992 in Rio de Janeiro, is considered a milestone marking a conscious turn of our civilization on a new path of development, in which man will try to live in harmony with nature. The existing environmental problems were analyzed. Humanity has realized the global environmental hazard and the threat of its own death, the need to search for new ways out of this situation.

\section{Conclusion}

Thus, an environmental and social management system is a set of procedures and practical measures that ensure the consistent implementation of your company's policies aimed at achieving your goals. The goal is to ensure that the necessary policies and procedures are in place and that they are consistently applied by your employees.

The management system helps to assess and control your risks and is the key to sustainable improvement of the situation. One of the most important aspects is the principle of continuous improvement - an ongoing process of learning, adjusting and improving your system. One of the elements of this system is the remuneration system. 
The use of incentive payments, depending on the results of a specialist's work and charged according to understandable and objective indicators, has a positive effect on the work of staff and the institution as a whole. The use of such a system affects the reduction of costs, the reduction of industrial conflicts, incentives for workers to improve their qualifications. When establishing performance indicators in an institution, the following principles should be followed:

- performance indicators must be established by categories of workers / positions;

- performance indicators should be objective and reflect the effectiveness and quality of work;

- performance indicators should take into account individual achievements and personal contribution to work results;

- performance indicators should contribute to the "transparency" of incentive payments.

Also, institutions should analyze the impact of the developed indicators and criteria, and, if necessary, refine them and update them.

\section{References}

1. G.V. Belov, Ekologicheskiy menedzhment, Ucheb. Posobiye (2016)

2. K.D. Byatova, Rol' ekologicheskogo ucheta i audita v global'nom ustoychivom razvitii, Sborniki konferentsiy NITS Sotsiosfera 9, 8-10 (2020)

3. L.N. Orlova, Ekologicheskiy menedzhment v praktike ekonomicheskoy deyatel'nosti khozyaystvuyushchikh struktur, Otkhody i resursy 2,7, 5 (2020)

4. A.A. Rementsov, Vnedreniye sistemy ekologicheskogo menedzhmenta (ISO 14001; ISO 14005) na predpriyatiyakh TEK, osnovnyye preimushchestva i soputstvuyushchiye riski, Ekonomicheskiye sistemy 1, 13, 135-142 (2020)

5. N.V. Svyatokho, Sistema ekologicheskogo menedzhmenta promyshlennogo predpriyatiya: sushchnost', standarty, etapy vnedreniya, Nauchnyy vestnik: finansy, banki, investitsii 1 (50), 178-186 (2020)

6. R.S. Stirmanova, Upravleniye zainteresovannymi storonami v sisteme ekologicheskogo menedzhmenta, Nauchnyy elektronnyy zhurnal Meridian 15 (49), 54-56 (2020)

7. Ye.G. Khorovinnikova, Organizatsiya upravleniya ekonomicheskimi protsessami predpriyatiya v oblasti ekologicheskogo menedzhmenta, Vestnik yevraziyskoy nauki 2 , 12, 77 (2020)

8. N.Yu. Shipilov, Ekologicheskiy menedzhment: strategicheskiy aspect, Aktual'nyye problemy ekonomiki i menedzhmenta 1 (25), 184-190 (2020) 